\title{
Lingual to Visual Transformation of Hujan Bulan Juni
}

\author{
Dini Faisal, Utami Dewi Pramesti, and Yulianti Rasyid \\ Universitas Negeri Padang \\ Indonesia \\ Dinifaisa109@gmail.com
}

\begin{abstract}
Hujan Bulan Juni was first published as a poem in 1994, and later in 2013 a short comic with similar title was created by a comic artist. This paper analyzes similarities between the poem, which is in lingual form and the short comic, which is in visual form. The purpose of this research is to understand whether there are similarities and differences in meanings caused by converting a literature work into visual work — called as komikalisasi. Research methodology for this study is qualitative descriptive with intertextual approach. Heuristic and hermeneutic analysis will be applied to comprehend meanings in lingual semiotic, while sequential image analysis will be used to comprehend visual meaning. Findings indicate a correlation of meanings between both poetical text and comic.
\end{abstract}

Keywords-lingual semiotic, visual meaning, komikalisasi

\section{INTRODUCTION}

A literary work does not exist by coincidence; it is commonly inspired by the previous works or imitation from its nature and environment. Therefore, mode shift of literary works from one genre to another is very common. Eneste (1991) defines ecranisation as 'the adapted to whiteboard', displacement or adoption of a novel (literary work) to a movie. In this case, ecranisation is defined as process of transforming sequences of words into a graphic/image or especially in the form of movie. One of the examples of ecranisation is adaptation of Laskar Pelangi novel to a movie with similar title.

In 2013, there was a comic entitled Hujan Bulan Juni (translated into Rain in June) which is inspired by a poem with identical title. This term then has known as poetry comicalization (komikalisasi) which is an example of mode shift. On a larger scale, Damono (2016) explains the term of alih wahana or mode shift as the process of transformation from one form (mode) to another. So, poetry comicalization is included as one form of mode shift (pengalihwahaan).

Comicalization of Hujan Bulan Juni (next HJB) is the first comicalization into a comic; it also published on several social media in Indonesia. Mr. Man or Mandjusman is a comic artist who adapts the poem of Sapardi Djoko Damono into a form of comic. This comic will be analyzed using Bahasa rupa (Visual Language). According to Tabrani (2009), Bahasa Rupa has its own language systematics, such as visual grammar which called as "tata-ungkapan" which can be translated as images visualization. As the result of an adaptation, comicalization of HJB has strong correlation with Damono's poem. However, the adaptation of HJB is created based on Man's self interpretation toward the poetry of Damono. This case becomes interesting because as a result of a self-interpretation, Man's subjectivity as the creator is cannot be avoided.

Research and discussion about HJB as a poem has been widely practiced. Generally, the discussion analyzed intrinsic and extrinsic structure of that poetry. In deeper perspective, there is semiotic analysis which analyzes about language signs to reveal the real meaning of the poetry. The difference between this article and previous studies is this article explains transformation or the changing of the language form - poetical text written by Sapardi Djoko Damono- into visual form and fine art (comic).

\section{METHOD}

This paper uses descriptive qualitative approach. This descriptive study attempts to explain the meanings of poetry text of Hujan Bulan Juni and the meanings of Visual language in the short comic of Hujan Bulan Juni. After analyzing both works separately, the next step will be comparing the meanings from both works, whether it has similarities or differences. Whether komikalisasi - transforming a poetry text into comic - affect the understanding and the meaning of the original Hujan Bulan Juni in poetry text. Heuristic and hermeneutic approach will be used to comprehend the meaning in lingual form while Bahasa Rupa will be used to analyzed the visual form.

\section{FINDING AND DISCUSSION}

First, each medium of works - the poetry text and the short comic of Hujan Bulan Juni-will be analyzed seperately. After understanding the meanings of each literature work then it will be compared, whether each works has correlation in meaning or no correlation at all. Semiotic theory is used to analyze the meaning of poetry text, and visual language to analyze the comic.

\section{A. Lingual Semiotics of A Poem Entitled Hujan Bulan Juni}

Poetry as a literary work uses attractive language (full of language style) and also solid in forming its meaning; it frequently arises a complex language signs. The understanding of language signs is known as semiotic. Fiske (2007) states that semiotic are a study about signs and how the signs work. In poetry, a word acts the sign. The process of understanding a word is not only in 
denotative level, but also connotative. Therefore, the misinterpretation of the signs (words) in poem causes incorrect interpretation to the content and its messages.

This is in line with Peirce (in Sobur, 2006) which states that there is not only language and communication system that are arranged by the signs, but also the world itself bounds with a whole human's thinking which are consisted with numerous signs. Therefore, human cannot establish a relationship with the reality. This study of the signs and its relationship is under semiotics perspective. Pradopo (2005) argues that semiotics is a study of sign systems which consist of a signifier and a signified. According to the relationship between signifier and signified, there are three main signs i.e, icon, index, and symbol.

A symbol is language sign which is non-natural or arbitrary; there is no necessary or natural relationship between the signifier and the signified. The relationship between those concepts is based on convention (agreement) of the society (Pradopo, 2010: 121-122). Due to its relationship to the society, the meaning of its symbol is highly determined by the environment and surrounding nature. This statement is the basic idea in the interpretation of HJB poem. Interpretation of poetry is done through "disassemble" of signs (words) in text towards its real meaning. This procedure was used to the study of ecranisation.

In another theory, Eco and Hoed (in Sobur, 2003) believe that semiotics is divided into two part of studies namely communication semiotics and sign semiotics. Furthermore, communication semiotic examines sign production which considers six factors in communication: sender, receiver (sign system), message, communication channel, reference (things to talk about), and pressure on sign theory and its understanding in certain context.

Related to the sign reading, Fiske (in Sobur, 2003) explains in more detail that there are three important things in semiotics; the sign, the code or system that organizes the sign, and the culture where the code and sign can operate. Therefore, it is necessary to notice those three signs to build complete understanding and comprehensive interpretation.

In author's note in the poetry collection of HJB: Sepilihan Sajak/Selected Verse (2016), Damono emphasizes that HJB was first published by Grasindo in 1994 and has printed several times. So, HJB is one of the poem titles in the collection of Damono's poetry book.

The interpretation of the meaning of HJB was started from title and year of its release. This poetry is written in 1989. For its context, see the figure 1 .

\begin{tabular}{|c|c|c|c|c|}
\hline \multirow{2}{*}{ Lokasi atau daerah } & \multicolumn{2}{|c|}{$\begin{array}{l}\text { Awal Musim } \\
\text { (dasarlan ke-) }\end{array}$} & \multicolumn{2}{|c|}{ Panjang Musim (dasarian) } \\
\hline & Kemarau & Hojan & Kemarau & Hujan \\
\hline $\begin{array}{l}\text { Pandeglang barat } \\
\text { Cilacap }\end{array}$ & \begin{tabular}{|l}
$\begin{array}{l}\text { Juni II } \\
\text { Mei III }\end{array}$ \\
\end{tabular} & $\begin{array}{l}\text { September III } \\
\text { Oktober I }\end{array}$ & $\begin{array}{l}10 \\
15 \\
\end{array}$ & $\begin{array}{l}25 \\
27 \\
\end{array}$ \\
\hline $\begin{array}{l}\text { Lampung selatan } \\
\text { Aceh tengah }\end{array}$ & \begin{tabular}{|l|} 
April III \\
Mei III \\
\end{tabular} & $\begin{array}{l}\text { November III } \\
\text { Oktober I }\end{array}$ & $\begin{array}{l}21 \\
13\end{array}$ & $\begin{array}{l}17 \\
23\end{array}$ \\
\hline Balikpapan & Juli I & Oktober I & 9 & 31 \\
\hline Gowa & Mei II & Oktober III & 16 & 20 \\
\hline Karangasem utara & Maret II & Desember I & 26 & 11 \\
\hline Lombok barat & Mei II & November III & 15 & 14 \\
\hline Halmahera & Juli III & Oktober III & 18 & 19 \\
\hline Jayapura & Mei I & November III & 19 & 17 \\
\hline
\end{tabular}

Fig. 1. Screenshot of monsoon table in Indonesia period 1971-2000

Based on figure above, it can be seen that rainy season in Indonesia on 1989 generally starts on September. It means rain in June is not ordinary case. In semiotics, 'rain in June' is a sign or nature symbol; its interpretation is influenced by the time of its writing.

Rain in June in the year of 1989 is a phenomenon because it is out of the regular. June should be a peak month of dry season which is marked by dry and crack soil. At that time, there should be no rain. Then, what is the association between HJB poem with patience, sensitive, and wisdom? Rain that is falling in the wrong time is a sign of unspeakable feeling and hidden burden; it is still saved until the time comes. When is the exact time? Yes, when rainy season comes. In order to wait the right time, someone needs an incredible patience; sensitive attitude and a lot of wisdom to keep also preserve that feeling to avoid damage and loss.

The next question, what is the hidden thing? The answer can be identified in the third row and first stanza: rintik rindunya/yearning in speck. In denotation meaning, rintik/speck in Indonesian Dictionary (KBBI) is written in entry rintik ${ }^{2} / \mathrm{rin}^{-}$ tik/ $n$ titik/dot (water splash and so on): -- dew; -- rain. It means rain in the form of specks or dots. Meanwhile, rindunya/his/her yearning which comes from rindu (yearning) word in Indonesian Dictionary KBBI as stated as below:

Yearning rindu/rindu/a 1 want and hopes badly toward something: ia -- akan kemerdekaan; he - of his freedom 2 strong hope to meet someone/something (wants to go home) : ia -- benar kepada anak-istrinya/he really - his wife and children ;-- jadi batasnya maka manis tak jadi cuka, pb/-- is the border thus sweet cannot be a bitter Too much honey is delicious, but it makes you sick to your stomach.

-- Lustful resentment; gives a love (to): -- dendam yang telah sekian lama terpendam dalam hati; prolong resentment

-- These violent delights have violent ends.

Meanwhile, in lingual semiotics, rintik rindunya/yearning in speck symbolize a deep passion of love, fondness and affection toward someone. However, that yearning is still tightly closed; she/he hides it under akar pohon berbunga itu/root of the flowering tree. Bunga (flower) which mean bagian tumbuhan yang akan menjadi buah, biasanya elok warnanya dan harum 
baunya; kembang: a part of a plant which potential to be a fruit; it has delightful color and pleasing smell - in Indonesian society, 'flower' identifies as perempuan karena perempuan penuh dan cinta keindahan (a woman, because of its full of love and beauty). Next, the line kepada pohon berbunga itu (towards (that) flowering tress) refers to a specific woman whom he so admires and hopes for. Thus, this first stanza can be interpreted as a deep longing for a charming woman. Based on the study on language signs, the interpretation toward the hidden and endured feeling before refers to a man towards a beloved woman (flowering tree).

In second stanza, the intense of the profound feeling about yearning and unrequited love is stronger but expressed calmly. Even though the force of love is too strong to be denied, however, this character prefers to forget even remove the signs/ traces of his feeling/yearning based on his own desires.

The third stanza or final verse in HJB poem represents the affirmation of the man's feeling even beyond his own desire. He prefers to resist his feelings of love, affection, and yearning and to silence it in his heart. However, the paradox then occurs in last two rows of this poem i.e., dibiarkannya yang tak terucap/ diserap akar pohon bunga itu/ he left it unsaid/absorbed by the root of that flowering tree. His unspeakable feeling was still kept tight and left to abate. However, he also secretly hoped that she would know it by herself.

\section{B. Visual Language of The Comic Hujan Bulan Juni}

According to Dziedric and Peacock in Duncan and Smith (2009), comics were originally a lower forms of mass entertainment. However, comics today have great potential as a complex expression medium in literature or visual art. The great potential of comics as a complex communication medium in expression and storytelling is quite interesting to analyze. Eisner (2000) further explains that the fundamental function of comics is to communicate ideas and / or stories using writing and drawing which involves the movement of images (time and timing) in a space.

To understand the visual language in comics, we must understand how the image depiction in the comics is visualized. Caputo (2003), mentions that comics have developed significantly, especially on the use of cinematographic visualization to obtain the desired effect. Moreover, Caputo argues that "artists can direct readers' responses (for example by creating a page with so much information that the reader will want to slow down, or by using "extreme" graphic techniques)".

Eisner (2000) emphasizes that "After all, this is the art of graphic story-telling. The codification becomes, in the hands of the artist, an alphabet with which to make an encompassing statement that weaves an entire tapestry of emotional interaction." Therefore, the understanding of visual language is very important to review the medium of comic so as the meaning contained in that media can be achieved thoroughly.

Some aspects that become the reference in analyzing the comics to achieve its visual meaning, namely:

1. Sequence, the direction of reading that is determined by the depiction of images and panels. Images or panels that are depicted larger than others indicate that the image is an important thing, so it will create a visual flow of reading.

2. Clarity in the setup and payoff depiction that refers to "any items that are to be a focus of attention later in a story should be set up in an earlier scene", (Caputo, 2003).

3. The use of point of reference in displaying the continuity of visual stories that refers to "one way to ensure continuity is to provide visual hints that serve as identifiers for characters or locations", (Caputo, 2003).

4. The use of cinematographic techniques such as shot distances and camera angles. Shot distances are divided into longshot, medium shot, close-up with some medium-length medium-length shooters and extreme close ups. Camera angles consist of normal view, low angle and high angle (bird-eye view). The depiction of shot distances and camera angles gives different meanings.

The comicalization of HJB poem consists of four comic pages consisting of three panels. The three verses of HJB poetry are depicted in twelve comic panels with the following divisions: the first stanza consists of six panels, second and third stanza have three panels. Of the twelve panels, only six panels have a word balloon, with the following divisions: each verse of poetry is divided into two word balloons. Based on these comparisons, there is an expanding meaning of lingual language when transformed into visual language.

To facilitate an understanding of the change of meaning from lingual language to visual language, analysis of the comic will be performed on each panel adapted to the verse of the poem. The first stanzas consist of six panels that are divided into three panels for half a verse of poetry. The first verse uses more panels than the other two verses because this verse requires visual representation as the opening. Here will be shown the main point of reference indicating where the events of this visual story occur as well as the atmosphere, the exact time and even the main character.

Based on the point of reference, then the background events in the comic is in the graveyard, which is a place that has many memories and can cause sadness and loss. The depiction of the rainy situation further reinforces the miserable impression of the visual story. It appears that the main character is a middle-aged man wearing a beret hat walking towards the tomb in the first panel. The second panel with extreme close up technique on the eye objects indicates that the man was paying attention to something. The third panel (zoom out) displays expression of a sad looking face (close up) from the man. Next, the panel is completed with a word balloon with the narration of first half-stanza "nothing more resilient than the rain in June." The impression raised by this panel is a tremendous courage through the far view of the man while it still displays the wistfulness as the supporting background. It can be seen in figure 2 . 


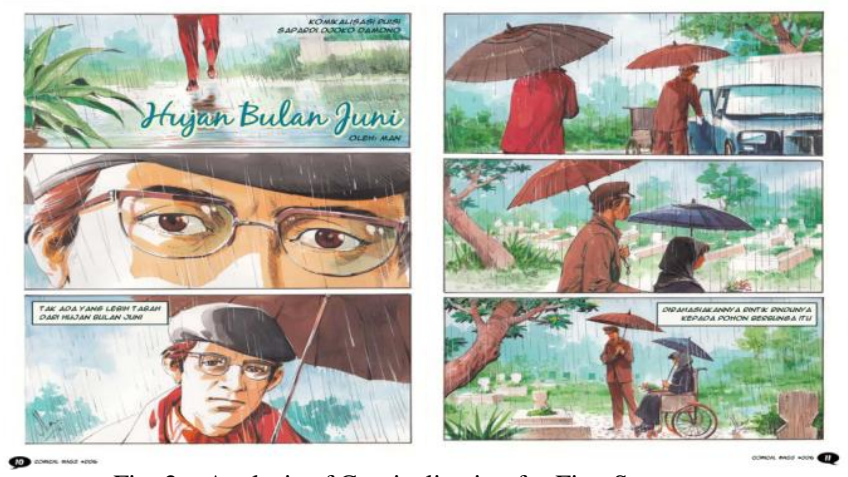

Fig. 2. Analysis of Comicalization for First Stanza

Analysis of visualization for the second stanza included only three panels, i.e., the panel from the seventh until the ninth. Similar to the depiction of first stanza, the scene was divided into half-stanza in each of word balloons. In the seventh panel, the depiction changes its point of view into third person point of view. Through this shift, the reader can identify that the main character was observing the two characters in the previous panel. The scene is emphasize through narration in the word balloon "nothing wiser than the rain of June." This panel was depicted by a long shot technique then indicates that the whole element, both character and scene depiction, is equally important. It can be seen in the figure 3 .

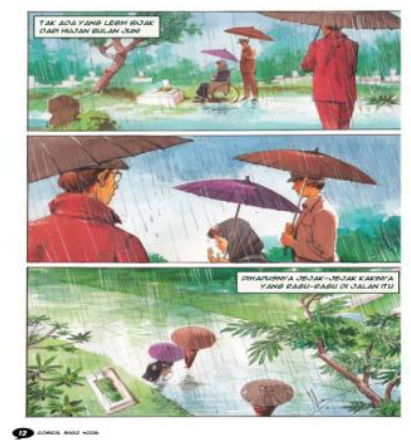

Fig. 3. Analysis of Comicalization for second Stanza

The eighth panel is in the medium shot style. The scene shows the man who was watching the woman character in prayer. The ninth panel uses a long shot technique with camera angle of bird-eye to provide a small and weak impression. The word balloon in this panel contains a narration "him swipe his shy footprints from that road." The word 'doubt' gives the impression of a weak attitude of the character. The shooting angle with bird-eye view shows dissappearnce of footprints on wet roads.

The third stanzaa of the HJB poem is depicted in three panels, the tenth panel to the twelfth panel. The tenth panel was depicted in medium shot and camera shift to position the main character visible from the front. The man was watching the bouquet of flowers thrown by the female character to the tomb. The portrayal of this panel focuses on the image of a bouquet of flowers and the gaze of the main character who concerns about flower. The word balloon in this panel contained a narrative: "nothing wiser than the rain in June." The eleventh panel is depicted in a close-up medium. This panel displays the departure of the female character and his driver from the tomb. The focus of this panel shows that the main character viewed the two characters that are going away. It can be seen in the figure 4.

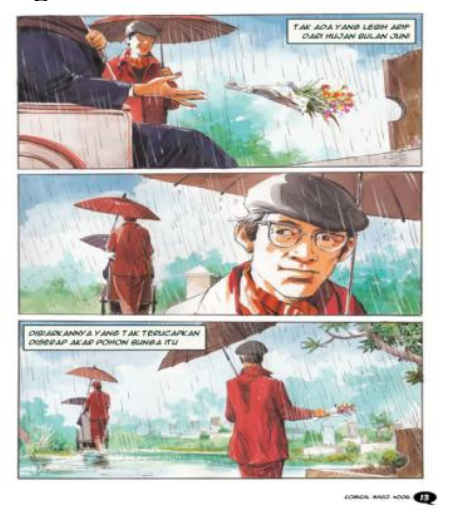

Fig. 4. Analysis of Comicalization for third Stanza 
The last panel is represented in a medium shot. In the background, the main character is highlighted on his back; he was watching the departure of the other two characters went away. In the next panel, the scene showed the main character holding a bouquet of flowers thrown by a previous female character. The narrative in the last panel is "let the unspoken absorbed by the root of the flowering tree." The word "unspoken" refers to the absence of dialogue between characters in comics and the use of narrative word balloons that look like a soliloquy.

C. Comparison between poetry text and short comic of Hujan Bulan Juni

Lingual form and visual form has different system of languages. Transforming poetry text into short comic may cause variation in meanings. In this section the meaning from both medium will be compared as seen in Table 1, only then we can find similarities and differences of meaning as a result of komikalisasi. It can be seen in the table 1below.

Table 1. Correlation of Lingual and Visual Meaning of Hujan Bulan Juni

\begin{tabular}{|c|c|c|c|c|c|}
\hline \multirow{3}{*}{ Stanza } & \multicolumn{4}{|c|}{ Meanings } & \multirow{3}{*}{ Correlation } \\
\hline & \multicolumn{2}{|c|}{ Lingual } & \multicolumn{2}{|c|}{ Visual } & \\
\hline & Signs & Meanings & Signs & Meanings & \\
\hline First stanza & $\begin{array}{l}\text { "rintik rindunya", } \\
\text { "bunga" }\end{array}$ & $\begin{array}{l}\text { Deep passion of } \\
\text { love, fondness, } \\
\text { affection for a } \\
\text { woman }\end{array}$ & $\begin{array}{l}\text { Rains, close-up of } \\
\text { eyes and face } \\
\text { expression of a } \\
\text { men, } \\
3^{\text {rd }} \text { person POV }\end{array}$ & Longing, sadness & $\begin{array}{l}\text { Yes, correlation in } \\
\text { longing and fondness }\end{array}$ \\
\hline Second stanza & "jejak kaki” & $\begin{array}{l}\text { Intense feeling of } \\
\text { yearning } \\
\text { expressed calmly }\end{array}$ & $\begin{array}{l}3^{\text {rd }} \text { person } \mathrm{POV}, \\
\text { graveyard, } \\
\text { bird eye view }\end{array}$ & $\begin{array}{c}\text { Longing, sadness, } \\
\text { unspeakable } \\
\text { memories, } \\
\text { loneliness, feeling } \\
\text { of weak and small }\end{array}$ & $\begin{array}{l}\text { Yes, correlation in } \\
\text { intense feeling of } \\
\text { yearning and loneliness }\end{array}$ \\
\hline Third stanza & $\begin{array}{l}\text { "dibiarkannya" } \\
\text { "tak terucap" } \\
\text { "diserap akar } \\
\text { pohon" }\end{array}$ & $\begin{array}{l}\text { Resignation, } \\
\text { hope }\end{array}$ & $\begin{array}{l}\text { Flower, } \\
\text { smile }\end{array}$ & $\begin{array}{l}\text { Unspeakable } \\
\text { feelings, hope }\end{array}$ & $\begin{array}{l}\text { Yes, correlation in } \\
\text { Hope and resignation }\end{array}$ \\
\hline
\end{tabular}

Table 1 above defines that there are similarities of meanings from both medias, poetry text and short comic. Although the signs from both medias are different but the overall meanings has a correlation.

\section{CONCLUSION AND RECOMMENDATION}

Poetry by Sapardi Djoko Damono used many rain-lingual symbols including his work on Hujan Bulan Juni. The lingual symbol used metaphorical (comparison) language style. The overall meaning of the poem describing a longing feeling or a restrained love. The first stanza is a restrained feeling either because it comes at an improper moment. The second stanza has the meaning of surrendering to fate and on third stanza the meaning of resignation is depicted strongly. The same meaning could be found in the comic such as the feeling of remorse, a restrained feeling and so on.

It can be concluded that there is a similarity of lingual and visual meaning even though both works in different medium were created by different person. The existence of similarities in lingual and visual language could be used as an alternative medium of teaching poetry in high school.

\section{References}

Caputo, T. (2003). Visual storytelling: the art and technique. New York: Watson-Guptill Publications

Damono, S. D. (2016). Hujan bulan juni: sepilihan sajak. Jakarta: Gramedia Pustaka Utama.

Departemen Pendidikan Nasional. (2008). Kamus besar bahasa indonesia. Jakarta: Gramedia Pustaka Utama.

Duncan, R and Smith, M. J. (2009). The power of comics: history, form \& culture. New York: The Continuum Internasional Publishing Group Inc.

Eisner, W. (2000). Comics and sequential art. Florida: Poorhouse Press.

Eneste, P. (1991). Novel dan film. Jakarta: Nusa Indah.

Fiske, J. (2007). Cultural and communication studies: suatu pengantar paling komprehensif, (Terj.Yosal Iriantara dan Idi Subandy Ibrahim). Yogyakarta: Jalasutra.

Pradopo, D. R. (2010). Pengkajian puisi. Yogyakarta: Gadjah Mada University Press.

Pradopo, D.R. (2005). Beberapa teori sastra, metode kritik, dan penerapannya. Yogyakarta: Pustaka Pelajar.

Pusat Perubahan Iklim dan Kualitas Udara, Kedeputian Bidang Klimatologi. (2011). Adaptasi dan mitigasi perubahan iklim di indonesia. Jakarta: Badan Meteorologi, Klimatologi, dan Geofisika.

Sobur, A. (2003). Semiotika komunikasi. Bandung: Remaja Rosdakarya.

Sobur, A. (2006). Analisis teks media: suatu pengantar untuk analisis wacana, analisis semiotik, dan analisis framing, cetakan keempat. Bandung: Remaja Rosdakarya.

Tabrani, P. (2009). Wimba, asal usul dan peruntukannya. Wimba: Jurnal Komunikasi Visual, Vol 01 No 01/2009, 1-7 